ECONOMIC GROWTH CENTER

YALE UNIVERSITY

P.O. Box 208629

New Haven, CT 06520-8269

http://www.econ.yale.edu/ egcenter/

CENTER DISCUSSION PAPER NO. 1004

\title{
Technology and Human Development
}

\author{
Gustav Ranis
}

Yale University

September 2011

Note: Center discussion papers are preliminary materials circulated to stimulate discussion and critical comments. 
Technology and Human Development

Gustav Ranis*

\begin{abstract}
Human development, in combination with technology, yields economic growth which, in turn, is necessary to generate further advances in human development. This paper focuses on the first channel above and finds the relationship significant. Secondly, the paper tries to investigate what affects technology change, as represented by TFP. We examine the influence of openness, FDI, patents and R\&D in a 22 country sample and also contrast Asian and Latin American experience.
\end{abstract}

Key Words: Technology, Human Development

JEL Codes: F00, F16, J24, O10, O15, O30, O31, O32

* The author wishes to acknowledge the excellent research assistance of Xiaoxue Zhao. 


\section{Introduction}

There can be little doubt that technology - both in its process and quality dimensions - when combined with human development - makes a critically important contribution to economic growth which in turn leads to advances in human development as a society's bottom line achievement. In a 1997 STICERD article "Development Thinking at the Beginning of the $21^{\text {st }}$ Century" Amartya Sen endeavored to distinguish between human progress by dint of BLAST, i.e., "achieved in Blood, Sweat and Tears," also known as savings and investment, and GALA, human advancement via the enhancement of capabilities generated by a combination of human development and technology (Sen, 1997).

BLAST itself has, of course, become less tearful over time as the Harrod-Domar world of constant proportions yielded to Solow's substitutability among inputs and the newly recognized sizable unexplained technology residual responsible for GDP growth. This exogenous technology change was indeed for some time seen as a "measure of our ignorance" and the holy grail to be incorporated into ever more sophisticated macroeconomic growth models. More recently, the advent of the "new growth theory" of Lucas (1988), Romer (1990) et al. meant that technology change has been endogenized and linked up more closely to education, health and other such inputs, i.e., approaching human development. But the objective remains GDP growth, which, in turn, leads to the bottom line, i.e. further improvements in human development.

What I intend to accomplish in this paper is, in the first instance, focus on the role of technology, in combination with human development, in generating the growth needed for further increases in human development. This relationship between 
technology and human development is an intensive one, running through growth as a critical instrument and to human development as the bottom line output. There are really two channels to be considered here. The first runs from economic growth to human development and is fueled by household and government expenditures, heavily influenced by the role of technology in converting household and government allocations of savings into advances in education, health and other dimensions of human development. This production function contains a role for technology in converting BLAST inputs into GALA outputs but it is not yet terribly well understood. A good deal of research has, of course, been done on the subject tracing the impact of single investments such as education expenditures coming out of economic growth by the state and the family on literacy or completed primary schooling. But the joint impact of interactions among education, health and nutrition inputs, etc., in generating human development advances is still far from fully understood. It has thus far proved difficult to determine exactly how technology change affects human development. We know that per capita income affects life expectancy levels and nutrition, etc., and that human development is positively affected by household and government expenditures on health and education. However, as much research, including that of Behrman (1990), has pointed out, there are many interrelated inputs, including home-schooling, home health inputs, the distribution of income as well as the relevance of household characteristics, plus alternative ways in which the public sector is organized, all of which makes it difficult to get a good fix on this production function. It reminds one of the problem encountered in earlier years, in determining agricultural sector productivity change, given multiple quantitative and qualitative inputs and the somewhat mysterious 
role of technology in converting expenditures on agricultural inputs into agricultural productivity achievements.

The second channel runs from human development back to economic growth, once again with technology playing an important role. In this paper I intend to focus on this second channel focusing on the impact of human development and technology on economic growth. Secondly, I intend to explore how technology measured by the TFP can itself be better explained. In the first instance, in other words, I want to show the importance of human development combining with technology in generating growth as an instrument for further improvements in human development. In the second instance, I want to delve more closely into what generates technology as represented by the TFP.

\section{Human Development, Technology and Economic Growth}

In comparison to the literature on the relationship between growth and human development, the literature on what generates economic growth is vast. Historically, much of it follows the neo-classical growth model of Solow (1956), followed by Barro and Sala-i-Martin (2004), Romer (1990), Lucas (1988) etc., as incorporated in the more recent endogenous growth literature. Much of this latter effort examines the role of education as well as of $R \& D$ and ideas as a source of growth, analyzing stocks of human capital that would put off diminishing returns and allow countries to grow at sustained rates indefinitely. As Lucas (1988), for example, points out, since education is smoothly substitutable for other inputs, investments in education are a critical "input" into growth. Indeed, the new growth theory literature already contains elements of human development as an input into generating growth, even if not necessarily defined in those terms. Technology is not explicitly incorporated, even as both neo-classical 
and new growth theorists agree that total factor productivity TFP represents the best measure of technology change and exercises a dominant influence on a country's growth performance. It is similarly understood that the HDI, especially if we focus on $\mathrm{HDI}^{\star}$, i.e., the HDI minus its income component, represents a good summary of the most important inputs into this particular production function. Thus, our first task is to understand the relationship between $\mathrm{HDI}^{*}$ and TFP as they jointly affect economic growth.

Table 1 presents GDP as the dependent variable and TFP as well as $\mathrm{HDI}^{\star}$, along with more conventional inputs like labor and capital, as the right-side independent variables. In all columns the dependent variable is the log of countries' annual GDP growth measured in $\$ 2,000$ US dollars. In all cases we have controlled for country fixed effects and included the countries' total labor force, the log of countries' total capital stock, and countries' TFP value as independent variables. Regressions one to three also include HDI*, i.e., the non-income human development index based on UNDP's Human Development Reports, including one-year and two-year lags, as independent variables. In all our regressions our results show that the coefficients of the TFP and the $\mathrm{HDI}^{\star}$ are also significantly positive indicating that technology and human development both positively contribute to economic growth. At the same time the fact that the coefficients on the one-year lag and the two-year lag of $\mathrm{HDI}^{\star}$ are significantly positive shows us that high levels of human development in previous periods are also positively associated with contemporary GDP growth. This implies that the positive correlation between human development and GDP is not due to reverse causality but that high levels of human development and of technology change both significantly improve economic performance. In regressions four, five and six we replace HDI* with 
education and lagged education, obtaining highly significant results indicating that the education component of $\mathrm{HDI}$ is undoubtedly the more important contributor within $\mathrm{HDI}$.

\section{Impacts on the TFP}

Let me now turn to our second task and examine what goes into the TFP variable itself. In spite of what we know to be its weaknesses, i.e., the residual includes economies of scale, terms of trade effects, etc. in addition to pure technology change, the TFP is generally accepted as the best yardstick of a country's innovative capacity. Ideally, we would like to know what determines that capacity, e.g. whether openness as modeled by exports and/or tariffs, FDI, R\&D, and various types of patents play significant roles. We will desist from pursuing other suggestions found in the literature, including the influence of geography, institutions, the extent of democracy, among others.

It is generally assumed that a country's openness to trade positively influences technology change. Keller (2004), among others, emphasized that technology change is determined in large part by technology diffusion carried in traded goods as well as by FDI across borders. Imported R\&D, especially if adapted to domestic conditions, is usually assumed to substantially raise domestic TFP, while trade with countries closer to the international technology frontier might be especially beneficial to developing countries, avoiding the need to invest a great deal of time and resources into the development of such technologies on their own. The key, of course, is the extent to which such frontier technologies are modified and adapted to local conditions. This concern includes the product as well as the process dimension of technology change, i.e., adaptiveness to domestic consumer tastes and needs, a subject frequently the 
main focus of innovative entrepreneurs, while process adaptation is concentrated on by most academic economists. The adaptation of international technology to new processes or products can be very important in decreasing capital intensity, making more efficient use of unskilled labor and offering consumers products more closely aligned with their preferences, all of which enhances TFP. While the factor proportions used to produce a given quality product differ substantially between the typical developed and developing country, this difference is typically smaller than the gap in the actual endowments.

Table 2 presents our OLS regressions examining the contribution of various leading suspects for the enhancement of 22 developing countries' TFP. In all regressions the dependent variable is countries' TFP value relative to the U.S., based on the estimates of UNIDO. Regression 1 includes exports over GDP as an indicator of openness to trade, net inflows of FDI over GDP, as well as both international and domestic patent applications. Regression 2 substitutes the lag of FDI inflows for current values. In both regressions the coefficients on exports are significantly positive, confirming that openness to trade is conducive to technology development. Interestingly, domestic patent applications clearly matter positively while international patents applications impact TFP negatively. This may be due to the frequently referred to possibility that foreign patents are used less to transfer technology and more to prevent entry, enforce market shares, restrict exports to third countries and the like. Turning to regression 3, we add another measure of openness to trade, a country's average applied tariff rate on all products, as well as another indicator of internal technology activity, a country's official R\&D expenditure as a percentage of its GDP. (Since the data for these added independent variables are only available starting from 
the 1990's, regression 3 contains a much smaller sample of countries.) The coefficients on both provide significant support for our hypothesis. Regression 4 again simply replaces net inflows of FDI in regression 3 with its lag, while regression 5 removes the percentage of GDP in exports as well as both types of patent applications so that the tariff rate becomes the sole indicator of openness to trade, and domestic R\&D the sole indicator of domestic technological activity. The consistently negative and significant coefficient on tariff rates in regressions 3 to 6 provide additional support for the importance of openness to trade while the consistently positive and significant coefficients on R\&D expenditures support the hypothesis of the importance of the official expenditures of this type in generating advances in TFP.

We should recognize, of course, that an individual entrepreneur and his capacity to make full use of technical knowledge from abroad is at best uncertain since technology is often tacit and the problems of communicating it and organizing it effectively, especially given long distances, institutional and cultural as well as geographic, render the implementation of such adaptation difficult. Since technology elements are only partially tradeable complementary institutional investments are required. It is for this reason that domestic patents, unlike international patents, as we see from our regression results (see Table 2), are likely to be especially helpful in converting tacit into explicit technical knowledge and TFP.

One of the impediments to openness is the resort to import restrictions both of the tariff variety and other under-the-radar mercantilist measures, including antidumping legislation, "buy domestic" legislation and the like. We, therefore, included tariffs in our regressions, along with export performance. Positive spillovers from foreign trade are likely to be more pronounced if they are accompanied by domestic 
adaptation. For example, a substantial increase in TFP in Japan in the late $19^{\text {th }}$ century took place as a result of the utilization of imported technology, the loom, in cotton spinning to replace an old one, the mule. In contrast to the Indian industry, the Japanese witnessed a virtually instantaneous switch from mules to looms which in turn prompted major adaptations in ancillary processes such as higher speeds of machinery in use, the introduction of cotton mixing and the employment of more women to repair the broken threads. Otsuka and coauthors (1998) attribute the overall decline in the capital/labor ratio in Japan around the turn of the century to this switch to the loom and the subsequent labor-using adaptation processes. In contrast, India continued to import new mules during the last part of the $19^{\text {th }}$ century and, for cultural reasons, failed to include women in the labor force, nor did they deploy cotton-mixing. As a consequence Japanese companies in China took away the Chinese markets from their India competitors.

FDI can carry technology but may also serve as a two-edged sword, i.e., multinational companies can stimulate technological change through labor training and the provision of high-quality inputs and trade connections but much depends on timing, i.e., the multinational corporation usually begins as a wholly owned subsidiary, becomes a joint venture and finally gives way to licensing or management contracts as the recipient country matures. In an idealized world, a disinvestment-transformation arrangement should be agreed upon ex ante in order to make the eventual transition easier. The independence of the multinational corporation, in particular during the customary early import substitution subphase, should be viewed as transitional if the relationship is not to sour, as, over time, it becomes less advantageous to the LDC and more advantageous to the FDI company. 
Inventive activity as summarized by patents clearly impacts TFP. As the 2001 Human Development Report noted, intellectual property rights are intimately intertwined with technology change because they make it possible for individual innovators to reap an eventual return on their investment. Foreign patents may lead to domestic patenting and an outburst of utility model patenting as we saw in the Japanese historical case (Otsuka et al.). Where utility models exist, they are especially helpful to medium and small-scale firms, and appear to have a high correlation with TFP.

Foreign patents, on the other hand, may restrict other technology entry, protect markets against local enterprise, restrict exports, and thus present a threat to the development of local industry. We therefore, distinguished between foreign and domestic patents and our econometric results fully support this decision. The 2001 Human Development Report noted that while TRIPS may benefit emerging developing countries such as Brazil, which are likely to profit from increased local innovation resulting from intellectual property rights legislation, LDCs which still lack formal innovation structures and institutions have faced higher costs without counterbalancing benefits. Thus, the impact of domestic patents on developing countries depends very much on the stage of development and it is no accident that the more entrepreneurial and successful developing countries of East Asia were intellectual property pirates for some time until they themselves became concerned about their own intellectual property rights being infringed upon by the next wave of emerging economies. Given the proper adaptation, developing countries can reap the benefit of investments and patents by rich countries in the invention process without having to incur relatively large costs, all of which has to do with the utilization of domestic patents and domestic R\&D. 
Since most R\&D takes place in developed countries the technology that results from these expenditures naturally yield North-biased technologies. Entrepreneurs in developing countries must be able to make effective use of such imported technologies. The educational system requires scientific vocational and technical literacy and not the simple copying of the educational system of the North. The aim must be to improve the skill level of the average LDC worker, including vocational education instead of academic education at the secondary level to encourage the appropriate adaptation of imported technologies and thus the strengthening of TFP. Science-based R\&D is defined as technology which arises from a change in our basic understanding of the laws governing the environment while empirically-based R\&D is based on trial and error. Tinkering or so-called blue collar R\&D in metal working, brick making, beer brewing, for example, made for TFP progress in Japan which did not need to rely on basic scientific advances. Historically, the US endowment favored empirically-based technology change while the German endowment, deficient in natural resources, shifted towards the engineering and chemical industries. As Kuznets (1966) has pointed out, using science wisely and selectively is related to the education system and to the types of interventions, direct or indirect, of government.

As we have shown, countries with higher levels of expenditure on R\&D experience higher rates of TFP since they are critical for the adaptive responses for international technologies we have discussed. Only $5 \%$ of the world's formal R\&D is expended by developing countries and the typical LDC spends only .5\% of its GDP on R\&D, compared with 5\% in developed countries. The East Asian economies spend between $1.5 \%$ and $3.0 \%$ of their GDP on formal R\&D while the Latin American countries fall below $1 \%$. The adequacy of domestic R\&D in terms of generating TFP hinges on 
fiscal incentives and institutional innovations as well as on education strategies. Large firms in the position of relative monopoly may have less incentive to innovate and, therefore, are less interested in R\&D. They are likely to prefer the stability of the status quo. In the successful developing countries, in particular in East Asia, it is in small and medium scale firms in relatively more competitive industries that the most significant R\&D activity took place. Wang and Tsai (2003), examining 136 Taiwanese firms between 1994 and 2000, found R\&D a significant determinant of TFP growth, i.e. every $10 \%$ increase in R\&D expenditures led to a $2 \%$ increase in the growth rate of TFP. Institutional innovations by the state, including the establishment of R\&D institutes, have also been very helpful to smaller firms that cannot afford major organized R\&D efforts. The Industrial Technology Research Institute, ITRI, in Taiwan, is a good example. The aforementioned utility model patent can be very helpful in this regard since much R\&D may be carried out in the form of tinkering or blue collar activities on factory floors and repair shops, including the famous "reverse engineering," not all of which is associated with piracy but none of which is captured in official R\&D statistics. An LDC may reap a higher payoff for its TFP from an imported machine if it was reverse engineered and redesigned by workers on the factory floor to suit the special needs of the local environment.

The emphasis here is clearly on adaptive rather than on basic R\&D. Most people agree that the greatest waste of all is second-rate scientific or basic research. It is not claimed that one can neglect basic science-focused R\&D entirely, particularly in such areas as agriculture and health. Without such research, the Green Revolution technology in agriculture would not have had the necessary sustaining power and the necessary defense against local pests and diseases. Similarly, in the field of health, 
few people would argue that a single transnational science can really be equally responsive to very different conditions around the world. This becomes relevant even in such activities as footwear production depending on cowhide tanning procedures which depend on the way cows are fed, or in tackling the textile industries' different humidity requirements. Minimal scientific literacy is necessary in some of these areas, even if it is ill-advised and expensive to attempt to show the flag in an array of frontier science endeavors.

We have made a number of comments contrasting Latin America and Asia. In Tables 3A and 3B we have tried to examine empirically whether there indeed exists such cross-regional differences in the relative importance of various influences on TFP. In these tables we have replicated the regressions of Table 2 for sub-samples of East Asian and Latin American countries, respectively. The coefficients on exports in regressions 1 and 2 and the coefficients on the tariff rate in regressions 3 to 6 , are already much stronger and more significant in the case of the East Asian countries, supporting the notion that openness to trade plays a larger role in strengthening TFP in that region. Equally interesting is the finding that the coefficients for R\&D in regressions 3 to 6 though equally significant, are bigger for the Latin American countries. Finally, we find a startling contrast in the impact of the two different types of patents in the two regions. While domestic patents continue to be significantly helpful to TFP in the East Asia case, with foreign patents significantly unhelpful, virtually the opposite holds for the Latin American countries, e.g. foreign patents are favored over the domestic type.

This contrast in what strengthens TFP between Asia and Latin America, as indicated by our empirical results, is instructive. In a typical Latin American country, say 
Brazil, much better endowed with natural resources and a lower labor-land ratio, the existence of natural resource bonanzas can lead to the relative neglect of the trade and human development. This is one manifestation of the natural resource curse and relates as well to the choice of education strategy. For example, Latin America's focus on the academic tract at the secondary level and a disproportionate emphasis on humanities-oriented tertiary education are in sharp contrast to East Asia's concentration on vocational education at the secondary level and on science and technology at the tertiary level. Latin America with its relatively strong unions applying pressure to delay trade liberalization, i.e., as measured by lower tariff reductions, felt secure in maintaining its import substitution policies longer, while East Asia was impelled by its lack of natural resources to shift early on to a more internationally competitive human resource-intensive growth path. The consequence was a substantially larger role for TFP: 2.6\% annually in Taiwan, compared to 1\% in Brazil between 1966 and 1991 (Young, 1995). On the other hand, Latin America's more inward-oriented policies induced more domestic R\&D in partial compensation for the lower impact of international variables on TFP.

\section{Summary and Conclusions}

The relationship between growth and human development is an iterative one. One production function runs from growth to human development, the other from human development to growth. In this paper our first objective was to examine the second strand, i.e. to establish that human development, lagged or non-lagged, in contribution with technology, measured by TFP, yields increases in the current rate of growth. We 
were also able to conclude that the education component of the $\mathrm{HDI}^{\star}$ (HDI minus the income component) makes an especially important contribution to economic growth.

We then turned to an examination of the independent factors determining the strength of TFP. We found that open markets, whether measured by exports or by low tariff rates enhance TFP. The same is true of FDI which enhances the ability to adapt imported technology to local environments. Interestingly, domestic patents are significantly helpful while international patents re not, indicating that the former may act to accommodate transferred technology while the latter is more likely to prevent entry, inhibit domestic technology, change as well as constrain exports to third countries. In the same vein we found that countries' R\&D expenditures significantly enhance TFP by their ability to further the adaptation to imported technology as well as to convert tacit into explicit technical knowledge.

Finally, we applied the same regressions separately to the Latin American and East Asian countries in our sample. Openness of the economy, as measured by export orientation and tariff rates makes a more pronounced and significant difference in the case of the East Asian countries as compared to Latin America. We, moreover, found that R\&D, though a significant contributor to TFP in both regions, plays a larger relative role in the more domestically oriented Latin American region. This difference is accentuated even more by our finding that while domestic patents contribute positively and international patents negatively in East Asia the exact opposite holds for Latin America. These results support the notion that natural resource rich countries are more likely to be inward-oriented while the resource poor East Asians relied more heavily on a human resource-intensive growth rate and achieved higher levels of TFP. 


\section{$\underline{\text { References }}$}

Barro, Robert J and Xavier Sala-i-Martin, Economic Growth, MIT Press, Cambridge, Mass.

Behrman, Jere (1990) 'The Action of Human Resources and Poverty on One Another'. Living Standards Measurement Study, Working Paper No. 74 (Washington, DC: World Bank).

Keller, W. (2004), 'nternational Technology Diffusion', Journal of Economic Literature, Vol. XLII (3), pp. 752-82.

Kuznets, Simon, (1966), Modern Economic Growth: Rate, Structure and Spread, Yale University Press, New Haven.

Lucas, R. (1988). 'On the mechanics of economic development.' Journal of Monetary Economics, 22(1), 3-42.

Otsuka, K., G. Ranis and G. Saxonhouse (1998) Comparative Technology Choice in Development: The Indian and Japanese Cotton Textile Industries (Basingstoke: Palgrave Macmillan).

Romer, Paul (1990) 'Endogenous Technological Change'. Journal of Political Economy 98 (5): S71-S102.

Sen, Amartya (1997) Development thinking at the beginning of the 21st century. DEDPS, 2. Suntory and Toyota International Centres for Economics and Related Disciplines, London School of Economics and Political Science, London, UK.

Solow, Robert (1956) 'A Contribution to the Theory of Economic Growth' Quarterly Journal of Economics 70: 65-94.

UNDP (United Nations Development Programme) (2001) Human Development Report 2001: Making New Technologies Work for Human Development (New York: UNDP).

Wang, J-C. and K-H. Tsai (2003), 'Productivity Growth and R\&D Expenditure in Taiwan's Manufacturing Firms', NBER Working Paper 9724, Cambridge, MA: NBER.

Young, Alwyn (1995) 'The Tyranny of Numbers: Confronting the Statistical Realities of the East Asian Growth Experience'. Quarterly Journal of Economics 110 (3): 641-680. 
Table 1

\begin{tabular}{|c|c|c|c|c|c|c|}
\hline & (1) & (2) & (3) & (4) & (5) & (6) \\
\hline VARIABLES & GDP & GDP & GDP & GDP & GDP & GDP \\
\hline \multirow[t]{2}{*}{ labor } & $0.546^{\star \star \star}$ & $0.551^{\star \star \star}$ & $0.556^{\star \star \star}$ & $0.530 * * \star$ & $0.536^{\star \star \star}$ & $0.542^{\star \star \star}$ \\
\hline & (11.9) & (12.1) & (12.06) & (12.98) & $(13.11)$ & (13.18) \\
\hline \multirow[t]{2}{*}{ capital } & $0.470^{\star \star \star}$ & $0.473^{\star \star \star}$ & $0.475^{\star \star \star}$ & $0.455^{\star \star \star}$ & $0.459^{\star \star \star}$ & $0.464^{\star \star \star}$ \\
\hline & (23.34) & (23.65) & (23.99) & $(24.03)$ & $(24.32)$ & (24.69) \\
\hline \multirow[t]{2}{*}{ TFP } & $1.647^{\star \star *}$ & $1.645^{\star \star \star}$ & $1.644^{\star \star \star}$ & $1.647^{* * \star}$ & $1.643^{* * *}$ & $1.641^{* * *}$ \\
\hline & (15.19) & (15.17) & (15.14) & (15.37) & (15.31) & (15.25) \\
\hline \multirow[t]{2}{*}{$\mathrm{HDI}^{*}$} & $0.451^{\star \star}$ & & & & & \\
\hline & (2.114) & & & & & \\
\hline \multirow[t]{2}{*}{$\mathrm{HDI}_{\mathrm{t}-1}^{*}$} & & $0.402^{*}$ & & & & \\
\hline & & $(1.924)$ & & & & \\
\hline \multirow[t]{2}{*}{$\mathrm{HDI}_{\mathrm{t}-2}^{*}$} & & & $0.358^{*}$ & & & \\
\hline & & & (1.738) & & & \\
\hline \multirow[t]{2}{*}{ education $_{\mathrm{t}}$} & & & & $0.667^{\star \star \star}$ & & \\
\hline & & & & (4.089) & & \\
\hline \multirow[t]{2}{*}{ education $_{t-1}$} & & & & & $0.606^{\star \star \star}$ & \\
\hline & & & & & (3.738) & \\
\hline \multirow[t]{2}{*}{ education ${ }_{t-2}$} & & & & & & $0.547^{\star \star \star}$ \\
\hline & & & & & & (3.383) \\
\hline \multirow[t]{2}{*}{ Constant } & $2.904^{\star \star \star}$ & $2.787^{\star \star \star}$ & $2.678^{\star \star \star}$ & $3.411^{\star * \star}$ & $3.252^{\star \star \star}$ & $3.097^{\star * \star}$ \\
\hline & (4.3) & (4.143) & (3.984) & $(6.295)$ & $(6.017)$ & (5.737) \\
\hline Observations & 631 & 631 & 631 & 631 & 631 & 631 \\
\hline R-squared & 0.996 & 0.996 & 0.996 & 0.996 & 0.996 & 0.996 \\
\hline
\end{tabular}


Table 2

\begin{tabular}{|c|c|c|c|c|c|c|}
\hline & (1) & (2) & (3) & (4) & (5) & (6) \\
\hline Variables & TFP & TFP & TFP & TFP & TFP & TFP \\
\hline \multirow[t]{2}{*}{ export } & $0.00223^{\star \star \star}$ & $0.00219^{\star * \star}$ & $\begin{array}{c}- \\
0.000945\end{array}$ & -0.00112 & & \\
\hline & (3.635) & (3.571) & $(-0.590)$ & $(-0.698)$ & & \\
\hline \multirow[t]{2}{*}{$\begin{array}{l}\text { non-resident patent } \\
\text { applications }\end{array}$} & $-2.16 e-06^{*}$ & $\begin{array}{c}-2.29 \mathrm{e}- \\
06^{\star \star}\end{array}$ & $\begin{array}{l}-4.25 e- \\
06^{\star \star \star}\end{array}$ & $\begin{array}{l}-4.39 \mathrm{e}- \\
06^{\star \star \star}\end{array}$ & & \\
\hline & $(-1.841)$ & $(-1.967)$ & $(-3.072)$ & $(-3.126)$ & & \\
\hline \multirow[t]{2}{*}{$\begin{array}{l}\text { resident patent } \\
\text { applications }\end{array}$} & $1.12 \mathrm{e}-06^{\star}$ & $1.18 \mathrm{e}-06^{\star \star}$ & $1.71 \mathrm{e}-07$ & $3.15 e-07$ & & \\
\hline & (1.912) & (2.047) & (0.153) & $(0.277)$ & & \\
\hline \multirow[t]{2}{*}{ FDI (net inflow) ${ }_{t}$} & 0.00433 & & $0.0162^{\star \star \star}$ & & -0.000306 & \\
\hline & (1.139) & & (2.699) & & $(-0.0682)$ & \\
\hline \multirow[t]{2}{*}{ tariff rate } & & & $\begin{array}{c}- \\
0.00521 * *\end{array}$ & $0.00551^{\star * *}$ & $-0.00398^{\star *}$ & $-0.00392^{\star \star}$ \\
\hline & & & $(-2.427)$ & $(-2.571)$ & $(-2.067)$ & $(-2.063)$ \\
\hline \multirow[t]{2}{*}{ R\&D expenditures } & & & $0.142^{\star \star \star}$ & $0.138^{\star \star \star}$ & $0.0685^{\star \star \star}$ & $0.0692^{\star \star \star}$ \\
\hline & & & $(4.122)$ & (3.969) & (3.419) & (3.486) \\
\hline \multirow[t]{2}{*}{ FDI (net inflow) ${ }_{t-1}$} & & 0.00558 & & $0.0158^{\star \star}$ & & 0.000741 \\
\hline & & $(1.372)$ & & (2.583) & & $(0.165)$ \\
\hline \multirow[t]{2}{*}{ Constant } & $0.361^{\star \star \star}$ & $0.359^{\star \star \star}$ & $0.424^{\star \star \star}$ & $0.438^{\star \star \star}$ & $0.430^{\star \star \star}$ & $0.426^{\star \star \star}$ \\
\hline & (26.64) & (26.51) & (6.691) & (7.011) & (12.15) & (12.78) \\
\hline Observations & 592 & 578 & 89 & 89 & 122 & 122 \\
\hline R-squared & 0.040 & 0.043 & 0.388 & 0.383 & 0.126 & 0.127 \\
\hline & & & & $C_{0}=$ & $*$ & \\
\hline
\end{tabular}


Table 3A

\begin{tabular}{|c|c|c|c|c|c|c|}
\hline & (1) & (2) & (3) & (4) & (5) & (6) \\
\hline Variables & TFP & TFP & TFP & TFP & TFP & TFP \\
\hline \multirow[t]{2}{*}{ export } & $0.00555^{\star \star \star}$ & $0.00556^{\star \star \star}$ & 0.00161 & 0.00156 & & \\
\hline & $(10.89)$ & $(10.91)$ & $(1.587)$ & $(1.612)$ & & \\
\hline \multirow[t]{2}{*}{$\begin{array}{l}\text { non-resident } \\
\text { patent applications }\end{array}$} & $-2.63 e-06^{\star \star \star}$ & $\begin{array}{c}-2.44 \mathrm{e}- \\
06^{\star \star \star}\end{array}$ & $\begin{array}{c}-3.65 \mathrm{e}- \\
06^{\star \star \star}\end{array}$ & $\begin{array}{c}-3.35 \mathrm{e}- \\
06^{\star \star \star}\end{array}$ & & \\
\hline & $(-2.895)$ & $(-2.710)$ & $(-5.555)$ & $(-4.932)$ & & \\
\hline \multirow[t]{2}{*}{$\begin{array}{l}\text { resident patent } \\
\text { applications }\end{array}$} & $2.23 \mathrm{e}-06^{\star \star \star}$ & $\begin{array}{c}2.23 e- \\
06^{\star * *}\end{array}$ & $\begin{array}{c}1.29 \mathrm{e}- \\
06^{* *}\end{array}$ & $1.12 \mathrm{e}-06^{*}$ & & \\
\hline & $(5.387)$ & $(5.460)$ & $(2.343)$ & $(2.042)$ & & \\
\hline \multirow[t]{2}{*}{ FDI (net inflow) $)_{t}$} & $-0.0188^{\star \star \star}$ & & $\begin{array}{c}- \\
0.00456\end{array}$ & & $-0.0229 * \star \star$ & \\
\hline & $(-3.463)$ & & $(-1.013)$ & & $(-3.823)$ & \\
\hline \multirow[t]{2}{*}{ tariff rate } & & & $\begin{array}{c}- \\
0.00163\end{array}$ & -0.00156 & $-0.00260 * *$ & $-0.00215^{\star}$ \\
\hline & & & $(-1.410)$ & $(-1.420)$ & $(-2.263)$ & $(-2.029)$ \\
\hline \multirow[t]{2}{*}{ R\&D expenditures } & & & $0.131^{\star \star \star}$ & $0.135^{\star \star \star}$ & $0.133^{\star \star \star}$ & $0.137^{\star \star \star}$ \\
\hline & & & $(7.857)$ & (8.279) & (10.98) & $(12.31)$ \\
\hline \multirow[t]{2}{*}{ FDI (net inflow) $)_{t-1}$} & & $-0.0220 * \star \star$ & & -0.00751 & & $-0.0259 * \star \star *$ \\
\hline & & $(-3.972)$ & & $(-1.668)$ & & $(-4.769)$ \\
\hline \multirow[t]{2}{*}{ Constant } & $0.178^{\star * \star}$ & $0.178^{\star \star \star}$ & $0.220 * \star \star$ & $0.220 * \star \star$ & $0.270^{\star \star \star}$ & $0.261^{\star \star \star}$ \\
\hline & $(14.63)$ & (14.61) & $(4.469)$ & $(4.798)$ & $(9.578)$ & $(10.57)$ \\
\hline Observations & 210 & 207 & 33 & 33 & 33 & 33 \\
\hline R-squared & 0.540 & 0.547 & 0.951 & 0.954 & 0.853 & 0.876 \\
\hline No & ndard ore & & $* *$ & $01, *$ & $5, *$ & \\
\hline
\end{tabular}


Table 3B

\begin{tabular}{|c|c|c|c|c|c|c|}
\hline & (1) & (2) & (3) & (4) & (5) & (6) \\
\hline Variables & TFP & TFP & TFP & TFP & TFP & TFP \\
\hline \multirow[t]{2}{*}{ export } & $0.00147^{*}$ & 0.00127 & -0.00317 & -0.00251 & & \\
\hline & $(1.851)$ & $(1.612)$ & $(-1.457)$ & $(-1.181)$ & & \\
\hline \multirow[t]{2}{*}{$\begin{array}{l}\text { non-resident } \\
\text { patent } \\
\text { applications }\end{array}$} & $\begin{array}{l}6.68 \mathrm{e}- \\
06^{\star \star \star}\end{array}$ & $6.51 \mathrm{e}-06^{\star \star \star}$ & $3.84 e-06$ & $3.49 \mathrm{e}-06$ & & \\
\hline & (2.855) & (2.833) & (1.199) & (1.131) & & \\
\hline \multirow[t]{2}{*}{$\begin{array}{l}\text { resident patent } \\
\text { applications }\end{array}$} & $1.45 e-05$ & $1.37 \mathrm{e}-05$ & $\begin{array}{c}- \\
0.000144^{\star * *}\end{array}$ & $\begin{array}{c}- \\
0.000148^{\star * *}\end{array}$ & & \\
\hline & $(1.252)$ & $(1.215)$ & $(-5.146)$ & $(-5.586)$ & & \\
\hline \multirow[t]{2}{*}{ FDI (net inflow) ${ }_{t}$} & $\begin{array}{c}- \\
0.00935^{\star * *}\end{array}$ & & -0.00823 & & $-0.00719^{*}$ & \\
\hline & $(-2.750)$ & & $(-1.384)$ & & $(-1.741)$ & \\
\hline \multirow[t]{2}{*}{ tariff rate } & & & 0.00235 & 0.00190 & 0.00421 & 0.00463 \\
\hline & & & $(0.558)$ & $(0.468)$ & $(1.176)$ & $(1.354)$ \\
\hline \multirow[t]{2}{*}{$\begin{array}{l}\text { R\&D } \\
\text { expenditures }\end{array}$} & & & $0.630^{\star * *}$ & $0.663^{\star \star *}$ & $0.197^{\star \star \star}$ & $0.206^{\star \star *}$ \\
\hline & & & $(6.392)$ & (7.080) & $(4.774)$ & (4.968) \\
\hline \multirow[t]{2}{*}{ FDI (net inflow) $)_{t-1}$} & & $-0.00791^{\star \star}$ & & $-0.0142^{\star \star}$ & & $-0.00844^{\star \star}$ \\
\hline & & $(-2.158)$ & & $(-2.313)$ & & $(-2.058)$ \\
\hline \multirow[t]{2}{*}{ Constant } & $0.443^{\star \star \star}$ & $0.442^{* * *}$ & $0.379 * * \star$ & $0.380 * \star \star$ & $0.363^{\star \star \star}$ & $0.358^{\star \star \star}$ \\
\hline & $(24.84)$ & (25.14) & $(4.657)$ & $(4.876)$ & $(7.170)$ & $(7.745)$ \\
\hline Observations & 347 & 337 & 50 & 50 & 83 & 83 \\
\hline R-squared & 0.089 & 0.086 & 0.556 & 0.588 & 0.298 & 0.308 \\
\hline $\mathbf{N}$ & $\sigma_{1}$ & & 0 & $01, * * \mathrm{p}$ & $5, * p<0$ & \\
\hline
\end{tabular}


